DOI:10.17951/h.2018.52.5.125-133

\begin{tabular}{lc}
\hline \multicolumn{1}{c}{ A N N A L E S } \\
UNIVERSITATIS MARIAE CURIE-SKŁODOWSKA \\
LUBLIN - POLONIA \\
VOL. LII, 5 & SECTIOH \\
\hline
\end{tabular}

Maria Curie-Skłodowska University in Lublin

\title{
BARTŁOMIEJ ZINCZUK
}

ORCID ID: https://orcid.org/0000-0003-2808-8510

b.zinczuk@poczta.umcs.lublin.pl

\section{Artificial Intelligence and Its Socially Responsible Use in the Modern Economy}

Sztuczna inteligencja i jej społecznie odpowiedzialne wykorzystanie we współczesnej gospodarce

Keywords: artificial intelligence; social responsibility; new economy

Słowa kluczowe: sztuczna inteligencja; odpowiedzialność społeczna; nowa gospodarka

JEL code: M14; M15; M19

\section{Introduction}

The dynamic development of digital technologies and the progressive integration of the human world with the world of machinery and equipment have provided companies with new opportunities to compete in an increasingly demanding global market. Technologies based on artificial intelligence (AI), the socially responsible use of which is a topical and important subject of public discussion, have become particularly significant in recent years in the modern economy. The aim of this article is to show the key issues related to companies' socially responsible use of AI in the modern economy. In the article, the author focuses on the characteristics of AI and a description of selected areas of its application, as well as showing the benefits, limitations and dilemmas resulting from the use of AI in the modern economy. The considerations presented in the article were based on studies of domestic and foreign literature as well as reports of analytical and advisory companies. 


\section{Artificial intelligence and its essence}

Artificial intelligence has been an increasingly popular topic and the subject of numerous public discussions and scientific studies in recent years. Due to its specificity and complexity, AI is extremely difficult to define. It includes algorithms, heuristics, genetic algorithms, expert systems, artificial neural networks, and fuzzy logic [Różanowski, 2007, p. 109]. The term "artificial intelligence" was first coined by the American mathematician John McCarthy at a conference in Dartmouth in 1956 [McCarthy et al., 1955]. There are many definitions of AI in the literature. According to Minsky, "artificial intelligence is the science of making machines do things that would require intelligence if done by men" [Minsky, 1968, p. 5]. Kurzweil describes $\mathrm{AI}$ as "the art of creating machines that perform functions that require intelligence when performed by people" [Kurzweil, 1992, p. 14]. Schalkoff describes artificial intelligence as "a field of study that seeks to explain and emulate intelligent behavior in terms of computational processes" [Schalkoff, 1990, p. 8]. According to its definition in a Polish language dictionary, AI is "a branch of computer science that studies the rules governing the mental behaviour of man and creates computer programs or systems that simulate human thinking" [Stownik Języka Polskiego]. According to the definitions given above, AI can be defined as actions aimed at reproducing human mental processes by means of computer devices and programs.

The literature outlines two approaches to the issue of artificial intelligence: "weak AI" and "strong AI". Weak AI is characterised by the use of certain aspects of human intelligence to improve the operation of an information system, while strong $\mathrm{AI}$ is able to mimic the way the human brain functions [LawIT, 2017].

Artificial intelligence and its development are linked to the fourth stage of the industrial revolution: "industry 4.0". The term "Industrie 4.0" appeared for the first time at the Hannover Fair in 2011 [Pfeiffer, 2017, p. 107], indicating that companies' production systems will in future consist of an information system and numerically controlled machines that will operate autonomously and have elements of AI [Wittbrodt, Łapuńka, 2017, pp. 793-799]. A characteristic feature of the fourth industrial revolution is the high share of modern technological solutions enabling automation and optimisation of production processes, preventive maintenance of machinery and equipment as well as faster adaptation of companies to market situations through the use of a huge amount of data in real time [Stadnicka et al., 2017, pp. 472-483]. Modern solutions based on digital technologies - in particular, solutions based on AI - are used not only in intelligent factories but also in various sectors of the economy and in everyday life. Artificial intelligence projects developed by companies such as IBM, Microsoft, General Electric, Google, Amazon, Facebook, and Apple support business processes, text and speech analysis and the performance of image analysis. Artificial intelligence solutions are a promising area of development, and the effects of the digital revolution are visible in almost every sector of the modern economy. 


\section{Areas of AI use in the modern world}

In recent years, the appreciable and strong development of digital technologies in particular, AI solutions - has attracted interest from both the scientific and business spheres. The opportunities offered by the practical application of AI solutions are vast. In today's economy, AI technologies can be seen in a wide variety of solutions [Różanowski, 2007, pp. 112-113]:

- technologies based on fuzzy logic concerning control of technological processes in production plants under conditions of missing data,

- expert systems supporting decision-making and reasoning,

- machine translation of texts,

- neural networks for signal processing and calculations,

- mining of data related to the process of discovering knowledge from databases,

- optical recognition for facial or object recognition,

- recognition of communicated content and speakers,

- recognition of handwriting,

- artificial art generating short literary forms or arranging and interpreting musical works,

- economics, assessing, for example, creditworthiness of borrowers and customer profiles, as well as supporting the planning of marketing campaigns.

The above-mentioned technological solutions indicate a huge potential for application and use of $\mathrm{AI}$ in various areas of business activity and spheres of human life. According to McKinsey \& Company, the analytics and advisory firm, certain technologies have the highest potential for AI development [McKinsey \& Company Report, 2017]:

- autonomous robots and vehicles,

- image recognition and processing technologies,

- speech processing and generation technologies,

- virtual assistants,

- machine learning.

The McKinsey Global Institute estimates that in 2016 the largest technology companies and companies of the digital era (including Apple, Amazon, Baidu, and Google) invested EUR 18-27 billion in the development of various AI technologies, with $90 \%$ comprising internal investments and $10 \%$ comprising external investments - intended, for example, for mergers and acquisitions [McKinsey \& Company Report, 2017]. Table 1 presents the value of external investments in companies engaged in the development of AI technology within a global perspective in 2016, expressed in billions of EUR.

Table 1 shows that the largest capital investments in 2016 concerned technologies of machine learning, image recognition and processing and natural language processing. Machine learning is related to the ability of machines to independently recognise the relationships between variables and make decisions based on their 
Pobrane z czasopisma Annales H - Oeconomia http://oeconomia.annales.umcs.pl Data: 26/04/2023 16:01:05

Table 1. Value of external investments in companies dealing with AI technologies in 2016 around the world (in billions of EUR)

\begin{tabular}{|c|l|c|}
\hline No. & \multicolumn{1}{|c|}{ AI technologies } & $\begin{array}{c}\text { Value of investments } \\
\text { (in billions of EUR) }\end{array}$ \\
\hline 1 & Machine learning & $4.5-6.5$ \\
\hline 2 & Image recognition and processing & $2.2-3.2$ \\
\hline 3 & Natural language processing & $0.5-0.8$ \\
\hline 4 & Autonomous vehicles & $0.3-0.5$ \\
\hline 5 & Autonomous robots & $0.3-0.5$ \\
\hline 6 & Virtual assistants & $0.1-0.2$ \\
\hline
\end{tabular}

Source: McKinsey \& Company Report [2017].

analysis. Machine learning is one of the key areas of AI, and the popularity of this technology is undoubtedly related to the growing demand for tools that can analyse large data sets characterised by increasing growth and complexity. Image and natural language processing technologies are extremely promising, and this is reflected in the investment decisions of companies. Image and natural language processing offers a wide range of possibilities related to the processing, recognition and analysis of images, photographs, maps, text and human speech, and solutions in this area are used in the economic, scientific and social spheres. Other technologies concerning autonomous vehicles, robots and virtual assistants, presented in Table 1, have aroused growing interest. According to experts, their use and importance will continue to grow in the near future, changing the face of the world we know today.

\section{Benefits, limitations and dilemmas resulting from the use of $A I$ in the modern economy}

The progress observed in the last dozen or so years in the field of digital technologies has introduced AI and its related technologies to almost all areas of everyday life. According to analysts at Gartner, in 2020, elements of AI will be found in almost all new software [Gartner, 2017]. According to the McKinsey Global Institute, the leading sectors in terms of AI implementation include: advanced technologies, telecommunications, automotive, financial services, energy and raw materials, media, entertainment, consumer products, transport and logistics, retail, education, professional services, healthcare, construction, tourism [McKinsey \& Company Report, 2017].

Artificial intelligence and its complementary technologies provide many possibilities resulting from AI's increasingly wide and multi-purpose application. One of the prospective areas of AI application is industrial production. An intelligent production system is characterised by cooperation, mutual connection, autonomous detection and learning, and the use of information about people, machines, materials and the environment in order to enable integration and optimisation of various activities of manufacturing companies [Li et al., 2017, pp. 87-89]. Artificial intel- 
ligence allows effective monitoring of the operation of machinery and equipment in real time, controlling the quality of the production process to detect anomalies and production defects, improving the production process and, above all, drawing conclusions that prevent future errors and failures. These activities allow for more efficient management of resources, which translates into a reduction of costs and the negative impact of industry on the environment.

Artificial intelligence is also increasingly noticeable in transport, forwarding and logistics. Modern technological solutions increase the efficiency of the transport chain and optimise its phases of production, storage and transport of goods to the customer. Artificial intelligence increases the efficiency of data analysis - e.g. choosing the best route depending on weather or road conditions, forecasting the demand and supply of transport loads as well as optimising the consumption of fuel needed for the physical distribution of goods. Thanks to the development of AI, autonomous vehicle projects have also been developed and implemented. Artificial intelligence technology enables vehicles to observe and understand the environment (with the use of sensors, cameras, and radar) and supports appropriate reactions, allowing a car to drive safely without a driver [PIM, 2017]. More and more companies are involved in road tests of autonomous vehicles (e.g. Tesla, Google, Uber, Lyft, Waymo, Baidu, Honda, Toyota, Audi, Mercedes, BMW, Volvo, Ford, and GM), and the rapid progress in the field of digital technologies together with the changes in legal regulations governing the operation of autonomous vehicles on public roads will allow the implementation of these modern transport solutions in the near future.

Healthcare and medical services are other areas with high potential for the use of AI. Effective medicine is increasingly focused on the individual characteristics of the patient, allowing planning of "tailor-made" therapies, which significantly increases the complexity of diagnostic and decision-making processes [Mikołajewska, Mikołajewski, 2011, p. 84]. In healthcare, AI can help doctors to diagnose diseases quickly, to precisely match treatment methods to individual patients and to predict the prevalence of particular diseases in society. In the future, AI will support the development and implementation of health prevention programmes for people at increased risk of incidence of particular diseases, the development of new treatments and medicines dedicated to individual patients as well as remote monitoring of patients' health through mobile medical devices.

The financial sector is also an area in which the use of AI technology is growing. Artificial intelligence allows automation and streamlining of many processes in financial institutions. Banks implement solutions based on the use of chatbots, i.e. systems replacing bank or call-centre employees in contact with the customer, improving customer service. Machine learning as a component of an AI system allows for early detection of unusual patterns of transactions, which may indicate abuse or attempted fraud, and also allows for automation of financial decisions used to assess a customer's creditworthiness or compliance with the criteria for granting an insurance policy [Krukowska, 2018]. Artificial intelligence in the financial sector 
also supports market data processing, which can be used for trading in securities portfolios and making investment decisions.

The examples of AI technology applications presented above comprise a mere fragment of the possibilities of this solution in selected sectors of the economy. Technological progress and its incessant pace continually reveal new areas in which human activity can be supported by modern technology. As in the case of any modern solution, a number of questions arise concerning the consequences of the implementation of digital technologies in economic, socio-cultural, ethical and legal dimensions or regarding the impact on the natural environment. Undoubtedly, any change has an element of uncertainty as to the form of the new reality and its positive and negative effects on the functioning of society.

Numerous scientific studies have been devoted to the industrial revolution 4.0 and, above all, the use of AI in business, including: robotisation and automation of production processes, use of bots and chatbots serving customers, introduction of solutions increasing the security of company operations, optimisation of business processes, efficient use of resources and cost reduction, as well as, above all, the use of large data sets for improved and faster adaptation of companies' offerings to the needs of buyers and to predict their future behaviour. The above-mentioned benefits associated with the increasing use of AI are undoubtedly considered an asset among the supporters of its implementation; however, there are also negative opinions concerning the technological expansion of this modern solution and its socially irresponsible use. Professor Stephen Hawking, in an interview on AI, expressed his fear that the creation of true AI (independent and self-aware) will be either the best or the worst thing in the history of mankind. He stressed that it is extremely important to direct work on the development of AI in the right direction, i.e. to create it in such a way that it will benefit humanity [Business Insider, 2018]. The creator of Tesla and SpaceX, Elon Musk, said that AI has much greater opportunities for development than anyone could imagine today, which may at some point in the future, as a result of its uncontrolled development, become a threat to humanity. Musk considers it crucial to establish an authority to control the development of AI technology, which is not fully understood, in order to ensure effective control over it [FXMag, 2018].

One of the key issues of social concern related to the use of AI in business is the forecasted change in the labour market in the near future. According to the PwC consulting company, modern technologies pose the greatest threat to occupations in industry and commerce. The PwC study shows that $30 \%$ of current jobs in the UK are vulnerable to automation, $38 \%$ - in the US, 35\% - in Germany and $21 \%$ - in Japan [PAP, 2017]. The response to the emerging risk of increased automation in the workplace, which may consequently have an impact on social sentiment, should include responsible national policies for professional retraining of employees working in vulnerable professions, creating effective mechanisms to regulate the labour market and promoting the acquisition of skills that will be useful for future work by people, and especially young people. 
Another example of threats resulting from the use of AI technology is the issue of responsible management and protection of large sets of data, which are its integral component. There may be a temptation to use data unethically or illegally, and therefore companies should focus on the best possible protection of information systems against misuse. The authors of a report on the malicious use of AI identify three areas of security (digital, physical and political) as particularly important, and they predict that in the near future there will be new types of cyberattacks using, among other things, automatic hacking, speech synthesisers, precisely targeted spam thanks to information extracted from social media and the exploitation of weaknesses in artificial intelligence systems [Malicious AI Report, 2018]. The authors of the report draw attention to possible threats such as the risk of taking control of, for example, entire fleets of autonomous vehicles for use in a terrorist attack. The report also draws attention to the political sphere, which is vulnerable to cyberattacks through the use of targeted propaganda and fake news in the form of audiovisual materials, which are highly effective tools for manipulating public opinion on a large scale. They propose actions to reduce the risks associated with the irresponsible use of AI by constantly raising the issue of cybersecurity, exploring models of openness in making information available, promoting a culture of social responsibility and seeking both institutional and technological solutions for protection against cybercriminals' attacks [Gazeta Ubezpieczeniowa, 2018].

The problem of the use of raw (e.g. rare earth metals) and other materials for the production of electronic devices is a crucial issue in the development of digital technologies and AI. The dynamic global development of the computer industry has highlighted the problem of environmental degradation manifested in the overexploitation of natural resources and the increase in electronic waste. The solution to this problem should be a socially responsible approach to the exploitation of natural resources, which is part of sustainable development, as well as effective promotion of recycling and manufacturing of electronic devices using technologies that will minimise the burden on the natural environment, both at the stage of production of electronic equipment and during its disposal.

\section{Conclusions}

Technological progress in the field of digital solutions, in particular the development of AI technology, has a fundamental impact on the functioning of the modern economy and society as a whole. Artificial intelligence is becoming more and more widely used in the economic activity of various companies and institutions, supporting people's work and daily lives. Artificial intelligence has gradually developed and improved, but this raises concerns related to the unknown long-term effects of its use. This provides an important stimulus for discussions and scientific research concerning its influence on various aspects of human life and its socially responsible 
application. It is essential to evaluate its impact on the socio-cultural, economic and natural environment in order to control not only its development but above all to identify future negative consequences of its application and effectively counteract them. The issues raised by the author in the article can be a starting point for further, in-depth discussion among the scientific and business communities regarding socially responsible use of $\mathrm{AI}$ in the modern economy. The issues of AI compliance with ethics and laws will be an area of further research for the author in the near future.

\section{References}

“Business Insider”. Profesor Hawking znów ostrzega ludzkość, https://businessinsider.com.pl/technologie/ profesor-stephen-hawking-o-sztucznej-inteligencji/ph31g7z [access: 20.08.2018].

FXMag. Czy Elon Musk boi się sztucznej inteligencji?, https://www.fxmag.pl/artykul/elon-musk-wyraza -obawe-wobec-sztucznej-inteligencji [access: 21.08.2018].

Gartner. AI technologies will be in almost every new software product by 2020. Gartner Press Releases, https://www.gartner.com/newsroom/id/3763265 [access: 26.07.2018].

„Gazeta Ubezpieczeniowa”. Złośliwe wykorzystanie sztucznej inteligencji, http://www.gu.com.pl/index. php?option=com_content\&view=article \&id=66209:zoliwe-wykorzystanie-sztucznej-inteligencji\&catid=53: wiat\&Itemid=107 [access: 25.08 .2018$]$.

Krukowska, M., Finanse w wyścigu po sztuczną inteligencję, "Obserwator Finansowy 2018”, https://www. obserwatorfinansowy.pl/tematyka/bankowosc/finanse-w-wyscigu-po-sztuczna-inteligencje/ [access: 8.08.2018].

Kurzweil, R., The Age of Intelligent Machines, MIT Press, US 1992.

LawIT. Sztuczna inteligencja vs. prawnik, http://lawit.pl/2017/07/18/sztuczna-inteligencja-vs-prawnik [access: 3.07.2018].

Li, B.H., Hou, B.C., Yu, W.T., Lu, X.B., Yang, C.W., Applications of artificial intelligence in intelligent manufacturing: A review, "Frontiers of Information Technology \& Electronic Engineering" 2017, Vol. 18(1).

Malicious AI Report. The Malicious Use of Artificial Intelligence: Forecasting, Prevention, and Mitigation, https://arxiv.org/ftp/arxiv/papers/1802/1802.07228.pdf [access: 21.08.2018].

McCarthy, J., Minsky, M.L., Rochester, N., Shannon, C.E., A Proposal for the Dartmouth Summer Research Project on Artificial Intelligence. August 31, 1955, “AI Magazine” 2006, Vol. 27(4), pp. 12-14.

McKinsey \& Company Report, Jak sztuczna inteligencja zmieni biznes w Polsce, McKinsey \& Company, „Forbes (Polska)”, https://mckinsey.pl/publikacje/raport-rewolucja-ai-jak-sztuczna-inteligencja-zmieni-biznes-w-polsce [access: 7.07.2017].

Mikołajewska, E., Mikołajewski, D., Wybrane zastosowania modeli komputerowych w medycynie, ,Annales Academiae Medicae Silesiensis" 2011, Vol. 65(1-2).

Minsky, M., Semantic Information Processing, MIT Press, Cambridge MA 1968.

PAP (Polska Agencja Prasowa). Robotyka i sztuczna inteligencja wplyna na rynek pracy, http://www.pap. pl/aktualnosci/news, 874350,robotyka-i-sztuczna-inteligencja-beda-mialy-rosnacy-wplyw-na-miejsca-pracy.html [access: 20.08.2018].

Pfeiffer S., The Vision of "Industrie 4.0" in the Making - a Case of Future Told, Tamed, and Traded, "Nanoethics" 2017, Vol. 11.

PIM (Polska Izba Motoryzacji). Autonomiczne pojazdy z wykorzystaniem sztucznej inteligencji, http://pim. pl/autonomiczne-pojazdy-z-wykorzystaniem-sztucznej-inteligencji/ [access: 14.08.2017].

Różanowski, K., Sztuczna inteligencja: rozwój, szanse i zagrożenia, „Zeszyty Naukowe Warszawskiej Wyższej Szkoły Informatyki” 2007, nr 2. 
Schalkoff, R.J., Artificial Intelligence: An Engineering Approach, McGraw-Hill College, New York 1990. Stownik Języka Polskiego, http://sjp.pwn.p1/sjp/sztuczna-inteligencja [access: 16.06.2018].

Stadnicka, D., Zielecki, W., Sęp, J., Koncepcja Przemyst 4.0 - ocena możliwości wdrożenia na przyktadzie wybranego przedsiębiorstwa, [in:] R. Knosala (red.), Innowacje w zarzadzaniu i inżynierii produkcji, Vol. 1, Oficyna Wydawnicza Polskiego Towarzystwa Zarządzania Produkcją, Opole 2017.

Wittbrodt, P., Łapuńka, I., Przemyst 4.0 - wyzwanie dla wspótczesnych przedsiębiorstw produkcyjnych, [in:] R. Knosala (red.), Innowacje w zarzadzaniu i inżynierii produkcji, Vol. 2, Oficyna Wydawnicza Polskiego Towarzystwa Zarządzania Produkcją, Opole 2017.

\section{Sztuczna inteligencja i jej społecznie odpowiedzialne wykorzystanie weźwspółczesnej gospodarce}

Obserwowany na przestrzeni kilkunastu lat dynamiczny postęp technologiczny w dziedzinie informatyki wpłynął na rozwój sztucznej inteligencji. Celem artykułu było ukazanie kluczowych zagadnień związanych ze stosowaniem sztucznej inteligencji przez przedsiębiorstwa w aspekcie jej społecznie odpowiedzialnego wykorzystania we współczesnej gospodarce. Autor skupił się na scharakteryzowaniu sztucznej inteligencji, opisie wybranych obszarów jej zastosowania oraz na korzyściach, ograniczeniach i dylematach wynikających z zastosowania sztucznej inteligencji we współczesnej gospodarce. Podstawę rozważań stanowiły studia literatury krajowej i zagranicznej oraz raporty firm analityczno-doradczych.

\section{Artificial Intelligence and Its Socially Responsible Use in the Modern Economy}

Dynamic technological progress in the field of information technology observed over several years has influenced the development of artificial intelligence. The aim of this article was to show the key issues related to the socially responsible use of artificial intelligence by companies in the modern economy. The author focused on the characteristics of artificial intelligence, a description of selected areas of its application and on showing the benefits, limitations and dilemmas resulting from the use of artificial intelligence in the modern economy. The considerations presented in the article were based on studies of domestic and foreign literature as well as reports of analytical and advisory companies. 